\title{
Conservation Management of the Banggai Cardinalfish in the Banggai Kepulauan District MPA - A Genetic Approach
}

\author{
Samliok Ndobe ${ }^{12^{*}}$, Daduk Setyohadi1 ${ }^{1}$, Endang Yuli Herawati ${ }^{1}$, Soemarno ${ }^{1}$ \\ and Abigail Moore ${ }^{2}$
}

\author{
${ }^{1}$ Faculty of Fisheries and Marine Science, Brawijaya University, Malang \\ ${ }^{2}$ (Fisheries and Marine Science Institute), Palu
}

\begin{abstract}
Abstrak
Banggai cardinalfish (Pterapogon kauderni, Koumans 1933), sering disingkat BCF, adalah jenis ikan yang berasosiasi dengan ekosistem terumbu karang dan bersifat endemik di perairan dangkal (kedalaman 0 sampai 5 meter) di sekitar Kepulauan Banggai. Terdaftar sebagai spesies "Endangered" pada IUCN Red-List, dinilai terancam oleh perdagangan internasional sebagai ikan hias. Pada tahun 2007, diinisiasi suatu Rencana Aksi BCF berskala nasional, dan Kawasan Konservasi Perairan Daerah (KKPD) di Kabupaten Banggai Kepulauan dicanangkan melalui SK Bupati, yang terdiri atas jejaring 10 pulau. Konservasi $P$. kauderni merupakan sasaran utama khusus dua pulau di antaranya. Dengan mereview data filogenetik, genetika dan biogeografi yang tersedia, maka jejaring KKPD ditinjau dari aspek konservasi genetika P. kauderni. Tanpa fase pelagis dan dengan site fidelity tinggi, populasi Banggai cardinalfish menunjukkan tingkat struktur genetika sangat tinggi khusus ikan laut. Sejumlah sub-populasi yang berbeda nyata dari aspek genetika telah teridentifikasi, hal yang mengindikasikan bahwa seharusnya unit (satuan) pengelolaan didasarkan pada sub-populasi (stok) yang ditentukan berdasarkan karakter genetika. Sejumlah knowledge gaps dan prioritas riset teridentifikasi. Secara khusus disimpulkan bahwa diperlukan sebuah program penelitian bertujuan mengidentifikasi serta melakukan karakterisasi setiap unit (satuan manajemen) berdasarkan genetika tersebut dari aspek biologi (termasuk genetika), ekologi (misalnya habitat/mikro-habitat) dan sosioekonomi (termasuk fishing grounds). Ditawarkan penyediaan management support melalui penggunaan spatial analysis tool MARXAN bersama dengan sebuah database SIG, untuk menghasilkan alternatif-alternatif zonasi berbasis sains dengan satuan/sasaran pengelolaan yang didasarkan atas struktur genetika populasi,
\end{abstract}

Kata Kunci: Pterapogon kauderni, Jenis terancam punah, Konservasi keanekaragaman genetik, Unit pengelolaan, MARXAN

\begin{abstract}
The Banggai cardinalfish (Pterapogon kauderni, Koumans 1933), often referred to as BCF, is a restricted range coral reef associated fish endemic to shallow waters $(0-5 \mathrm{~m})$ around the Banggai Archipelago, Indonesia. Listed as "Endangered" in the IUCN Red-List, the international marine aquarium trade and habitat degradation are considered major threats. In 2007, a national BCF Action Plan was developed, and a District MPA was established by decree of the Banggai Kepulauan District Head, consisting of a network of 10 islands. For 2 of these P. kauderni conservation is the main management target. We reviewed available phylogenic, genetic and biogeographical data, and examined the MPA network from the viewpoint of $P$. kauderni genetic diversity conservation. With no pelagic phase and high site fidelity, the Banggai cardinalfish population exhibits a level of genetic structure unusual in a marine fish. Several genetically distinct sub-populations have been identified. It was concluded that management units should be based on genetically determined sub-populations (stocks). Critical knowledge gaps and several research priorities were identified. In particular, we conclude that a research programme is necessary for the identification and characterisation of these genetically determined units from biological (including genetic), ecological (e.g. habitat/micro-habitat) and socio-economic (including fishing ground) aspects. We propose to provide management support through the use of the spatial analysis tool MARXAN combined with a GIS database to produce science-based zoning options with management units/targets based on genetic population structure.
\end{abstract}

Key words: Pterapogon kauderni, Endangered species, Genetic diversity conservation, Management units, MARXAN

"Corresponding Authors : samndobe@yahoo.com 


\section{INTRODUCTION}

Indonesia is often called a "Megabiodiversity" country, and the Coral Triangle is one of the three major global biodiversity regions, ranking alongside the Amazon and Congo basins. Indonesia as a signatory to the Convention on Biological Diversity (CBD) is committed to biodiversity conservation, however the high level of anthropogenic pressure (direct and indirect) means that an increasing number of species are at risk of extinction. There is a growing awareness that simply conserving parts of an ecosystem or a certain number of individuals of a species is often not enough. In addition, genetic diversity between individuals and between populations or subpopulations of a given species is also important, as is acknowledged in the CBD text. However in the Agenda 21 document (produced at the 1992 United Nations Conference on Environment \& Development held in Rio de Janeiro, Brazil) which was intended as a technical guideline for CBD implementation, genetic diversity is only discussed for terrestrial plants and animals.

There is growing concern about aquatic species, including freshwater and marine organisms. Examples of this trend can be seen in a recent review of the IUCN Red List (Vié et al. 2009), recent proposals to CITES (see http://www.cites.org); species added to the list of flora and fauna protected in Indonesia under the Appendix to Law PP No7 1999 (http://www.dephut .go.id/INFORMASI/UNDANG2/pp/L_7_99 $. \mathrm{htm})$; and the Census of Marine Life CoML (http://www.coml.org). This concern is also increasingly extended to the conservation of genetic diversity within species (e.g. Gray, 1997; Conover et al. (2006).

One factor which tends to affect genetic diversity within a species is the level of reproductive isolation between populations which in extreme cases can be total, with no gene flow for many generations. Isolated populations or sub-populations tend to become genetically distinct due to genetic drift, site-specific selection and a variety of stochastic factors such as founder effects and one-off or infrequent impacts which can significantly reduce effective population numbers at a particular point in time, leading to genetic bottlenecks (Bertorelle et al., 2009). It is now widely considered that, in the conservation management of species with reproductively (and therefore genetically) isolated populations, each such population or sub-population should be treated as a separate management unit. This is specifically so in the case of marine fish, where each such unit can be considered as a separate stock (e.g. Reis et al., 2009; Rocha et al., 2007).

Sustainable management of marine fisheries resources, including the use of Marine Protected Areas (MPA) as a fisheries management tool, should be based on these genetic sub-populations or stocks (Palumbi, 2003), leading to a need for population genetics studies for their identification and characterisation. As pointed out by Hellberg (2007), such identification is now possible due to the development of technology for genetic (DNA) analysis, using a variety of approaches. One powerful support tool is GenBank, a global database of DNA and other proteins, hosted by several sites, including in particular the National Center for Biotechnology Information. Gen Bank and a number of other tools (e.g. software for genetic data analysis) can be accessed for free at http://www.ncbi.nlm.nih.gov/. Other software for genetic and phylogenic data analysis which are available on-line and/or downloadable include GENEPOP (http://genepop.curtin.edu.au) and PAST (http://www.nhm.uio.no/norges/past/downl oad.htm).

One marine species of conservation concern is the Banggai cardinalfish Pterapogon kauderni (Koumans, 1933), a small (maximum standard length around 65 $\mathrm{mm} \mathrm{SL}$ ) restricted range endemic species with an endemic distribution limited to the southern part of the Banggai Archipelago and a few nearby islands (Vagelli, 2005). Traded internationally as a marine ornamental since the 1980's. These sites include Lembeh Straits (Erdman and Vagelli, 2001); Palu Bay (Moore and Ndobe, 2007a);dobe et al., 2005), introduced $P$. kauderni populations have become established at several sites along the long and complex trade routes. 


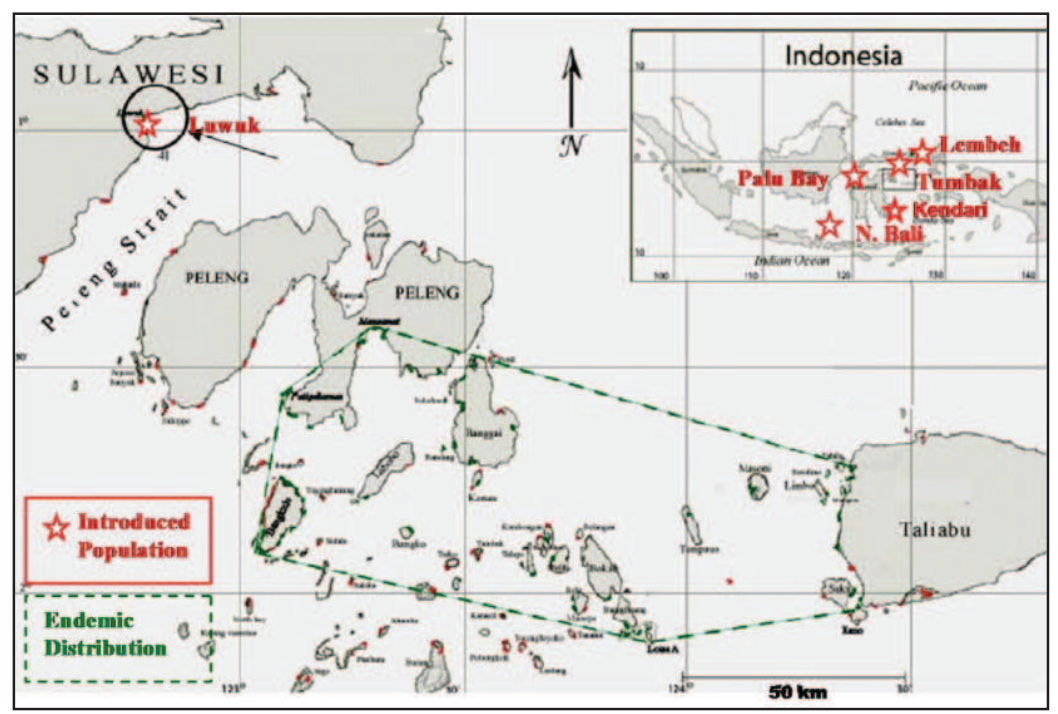

Sources: Vagelli (2005); Erdman and Vagelli (2001); Vagelli and Erdmann (2002); Moore and Ndobe (2007a); Ndobe et al. (2005); Lilley (2008): Moore et al, (2011)

Fig. 1. Known endemic and introduced $P$. kauderni populations

Tumbak(Ndobe et al., 2005); North Bali (Lilley, 2008) Kendari (Moore et al, ;2011 in theseproceedings); and Luwuk (Vagelli and Erdmann, 2002), though there has been speculation that the Luwuk population might be a remnant of a once more extensive $P$. kauderni population on the Sulawesi mainland (Vagelli, 2005).

The known $P$. kauderni endemic distribution and introduced population sites are shown in Fig. 1, though it is likely there have been further as yet unpublished introduced populations established. The endemic distribution area covers around $5,500 \mathrm{~km}^{2}$, while the total area of available habitat has been estimated at around 30$34 \mathrm{~km}^{2}$ and the total endemic population has been estimated at around 2.4 million (Vagelli,2005). It is considered likely that there may have been further (as yet unpublished) introduced populations established.

A paternal mouthbrooder with direct development, there is no pelagic dispersal phase in the $P$. kauderni life-cycle and recruits settle in the substrate near the site of their release (Vagelli, 1999). Despite an ontogenetic shift in micro-habitat use (Vagelli, 2005; Ndobe et al. 2008), P. kauderni exhibits a high site fidelity thereafter (Kolm et al., 2005). The shallowwater habitat (coral reefs, reef flats and seagrass beds under $5 \mathrm{~m}$ depth, mainly $0.5-3 \mathrm{~m})$ and sedentary habit make $P$. kauderni extremely easy to catch. These factors, combined with relatively low fecundity and a suspected high rate of mortality due to predation of recruits and juveniles, make this species especially vulnerable to extinction, with a particularly high risk of local extinction due to the lack of natural dispersion mechanisms leading to an extremely low probability of natural recolonisation

Considerable international attention has been focussed on the risk of extinction due to the marine aquarium trade (e.g. Bruins et al., 2004; Vagelli, 2008). Since 2007, management of the fishery has greatly improved but growing threats due to habitat and especially micro-habitat loss have been identified, in particular the increasing consumption of sea anemones and sea urchins. Though some other community members are involved, the main consumers are seaweed farmers who are tending to collect these and other invertebrates as a major source of protein in their diets (Ndobe et al., 2008; Moore et al., 2011)

Pterapogon kauderni is listed as ENDANGERED in the IUCN Red List (Allen and Donaldson, 2007) and was proposed for CITES listing in 2007 (CITES, 2007a) by the United States of America. However the proposal was withdrawn (CITES, 2007b) whit Indonesia making a commitment to the sustainable management of this species (Indrawan and Suseno, 2008; Moore and Ndobe 2007b). A multi-stakeholder, multiyear Banggai Cardinalfish Action Plan was 
developed, and a number of activities have been implemented to achieve the goals agreed (Ndobe and Moore, 2009; Moore et al., 2011). A District Marine Protected Area (MPA), or more accurately a Marine Protected Area Network (MPAN) was established by Decree of the Banggai Kepulauan District Head (SK Bupati $540 / 2007)$. Two out of the ten islands listed (Pulau Banggai and Pulau Togong Lantang) are designated specifically for the conservation of the Banggai cardinalfish. This MPA is still in the planning stage.

The habitat and dispersal limitations have resulted in a geographically discontinuous $P$. kauderni population distribution pattern, with a very low likelihood of interbreeding between all but the closest of populations, separated by shallow water with suitable habitat. It is therefore considered likely that each of these geographically isolated populations is in fact a separate sub-population or stock with significant genetic divergence or differentiation between stocks. Local extinctions are likely to result in the total loss of genetic strains so that the identification of these stocks is important for species conservation management, both from a fisheries management point of view and in the context of MPA planning and management.

\section{METHODS}

The state of knowledge regarding the phylogeny, biogeography and genetic structure of the endemic Banggai cardinalfish (Pterapogon kauderni) was assessed through a review of published scientific literature as well as "grey literature", supplemented by direct observation and key informant interviews (primary data). The data and information thus obtained were analysed to evaluate the MPA network from the viewpoint of $P$. kauderni genetic diversity conservation, in particular in relation to the spatial planning process for the District MPA Network. Specific aims were to identify critical knowledge gaps and to propose a possible approach towards effective BCF conservation management from a genetic biodiversity standpoint.

\section{RESULTS AND DISCUSSION}

\section{Pterapogon kauderni phylogeny and biogeography}

The Dutch naturalist Walter Kaudern collected 2 (type) specimens of a new species from the coastal waters around Banggai Island during an expedition in 1917-1920. These were deposited with the

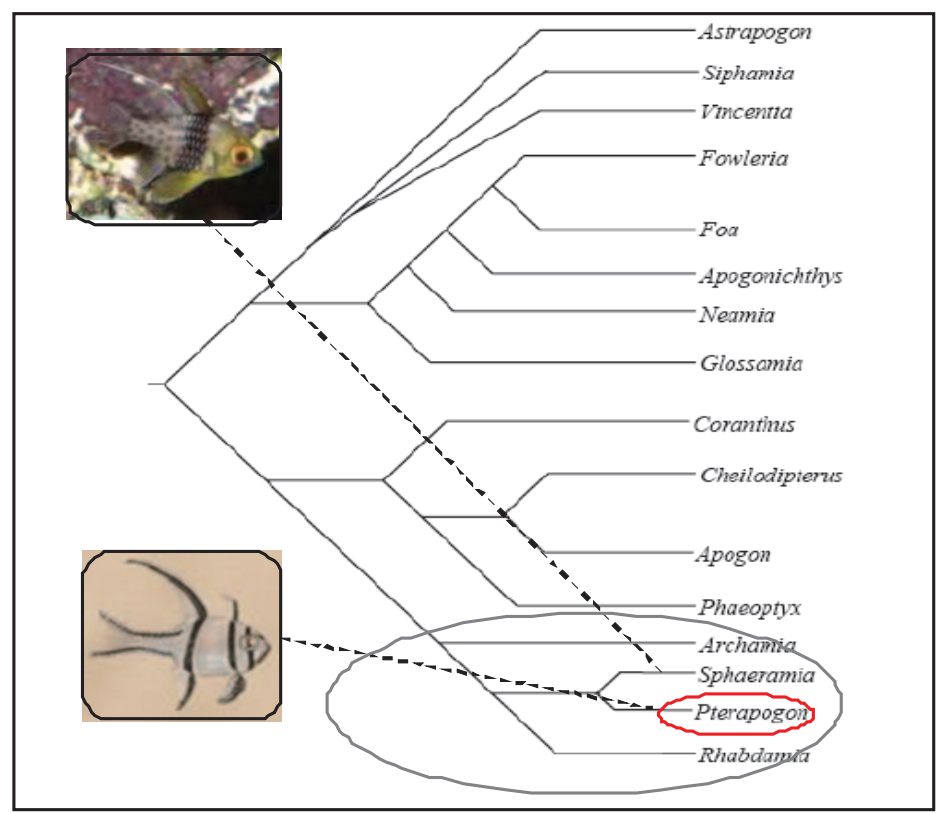

Source: Fraser (1972) in Gouws \& Gon (2009)

Fig. 2. A Simplified phylogeny of the Apogonidae 
Leiden Museum and later described by Frederick Koumans. Placed in the Family Apogonidae (cardinalfishes), several unusual features warranted the establishment of a new Genus Pterapogon, while the species name kauderni was given in recognition of the discovery by Walter Kaudern (Koumans, 1933). Commonly used local names are bebese tayung (Bajo language) and capungan (Banggai language) while other trade names include the abbreviation BCF, capungan Banggai and high-fin cardinalfish (Ndobe et al., 2005). The classification of Pterapogon kauderni in the global database FishBase (http://www. fishbase.org) is as follows:

Superclass: Osteichthyes (bony fishes)

Class: Actinopterygii (ray-finned fishes)

Order: Perciformes (perch-like fishes)

Family: Apogonidae (cardinalfishes)

Sub family: Apogoninae

Genus: Pterapogon

Species:Pterapogon kauderni

(Koumans, 1933)

Common name: Banggai cardinalfish

According to Gavin and Gows (2009), the Cardinalfishes or Apogonidae are small, carnivorous fish. The majority are reef-associated, while some live in deepwater, estuarine or freshwater habitats. There are two generally recognised Sub-families, the Apogoninae and Pseudaminae with around 23 Genera and over 250 species, with the highest diversity being found in the Indo-Pacific region. The most complete phylogeny to date was compiled by Fraser (1972), and is shown in a simplified schematic form in Fig. 2. Based on osteology \& morphology, Frazer (1972) ordered the Apogonidae based on what were considered the most basic to the mostadvanced traits. $P$. kauderni was placed in the same Clade as the Genus Sphaeramia, while the two neighbouring Clades (Archamia \& Rhabdamia) were both considered monophyletic.

There is a physical resemblance between Sphaeramia nemtopterus (a widespread cosmopolitan species) and $P$. kauderni. Both have vertical stripes and a thin high body unlike the horizontal stripes and elongated rounded body more common in cardinalfishes. While the differences are striking to ichthyologists familiar with both species, this superficial resemblance has lead to cases of mistaken identity, with several reports of $P$. kauderni sightings which on examination by local scientists familiar with $P$. kauderni turned out to be Sphaeramia nemtopterus. The behaviour and habitat of the two species are quite different, S. nemptopterus being relatively mobile and favouring mid-water habitat around almost any form of structure (natural or man-made), while P. kauderni is benthic and sedentary.

Advances in genetic analysis (technology, software) have lead to the development of phylogeny based on DNA with more detailed and/or accurate studies of evolutionary/phylogenic relationships between taxa at many levels Genetic studies of Apogonidae published to date (e.g. Gouws \& Gon, 2009; Thacker \& Roje, 2009) still cover relatively few taxa. Despite this limitation, the results of these studies question previous classifications based on morphometric, biogeographical \& ecological considerations, and phylogenic relationships within the Apogonidae are under revision. Based on the analysis of 3 types of mitochondrial DNA, Thacker (2009) placed the Family Apogonidae in Sub-order Apogonoidei, as a sister clade alongside the Gobioidei and Kurtoidei in the Order of Gobiiformes. Thacker and Roje (2009) developed this analysis to produce a phylogenic tree shown in Fig. 3.

Thacker (2009) and Thacker and Roje (2009) considered that the theory of a close relationship (relatively recent common ancestry) between the Apogonidae and Gobioidei is supported by data, including data from the fields of morphometry, biogeography, ecology, and reproductive biology. Vagelli (2009) postulated that the ancestral species of the Gobiiformes, including the Apogonidae, could be freshwater fish from Australasian plate, which evolved before the fragmentation and subsequent movement of the various plate fragments as shown in Fig. 4. 


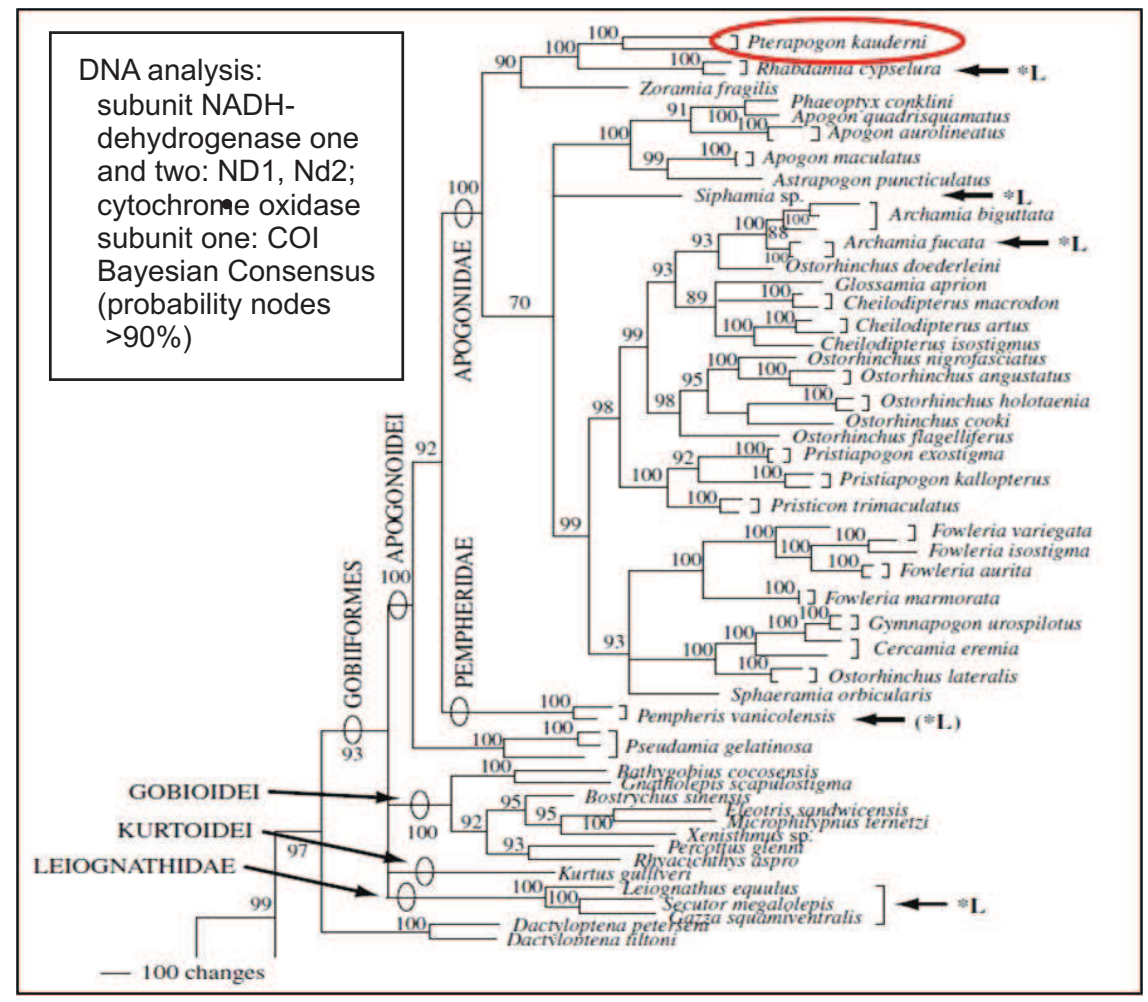

Source: Thacker \& Roje (2009)

Fig. 3. Phylogenic Tree based on 3 types of mitochondrial DNA

According to this theory, $P$. kauderni would have evolved during the northwest movement of the plate comprising the Banggai Islands and western Taliabu. Thus, when eventually the plates attained their current positions, $P$. kauderni would have been present on this plate fragment but not on any of the adjacent plates. With no planctonic dispersal phase and a sedentary habit, the species would have been unlikely to spread far (if at all) thereafter. Several species known to exhibit traits rare in marine fish but not uncommon in freshwater fish, in particular a similar reproductive biology (large egg size, mouthbrooder with direct development) include P. kauderni, Quinca (or Pterapogon) mirifica, the Genus Glossamia and Genus Vincentia. Vagelli (2009) considered that these traits could be explained by this theory of common globoid ancestor.

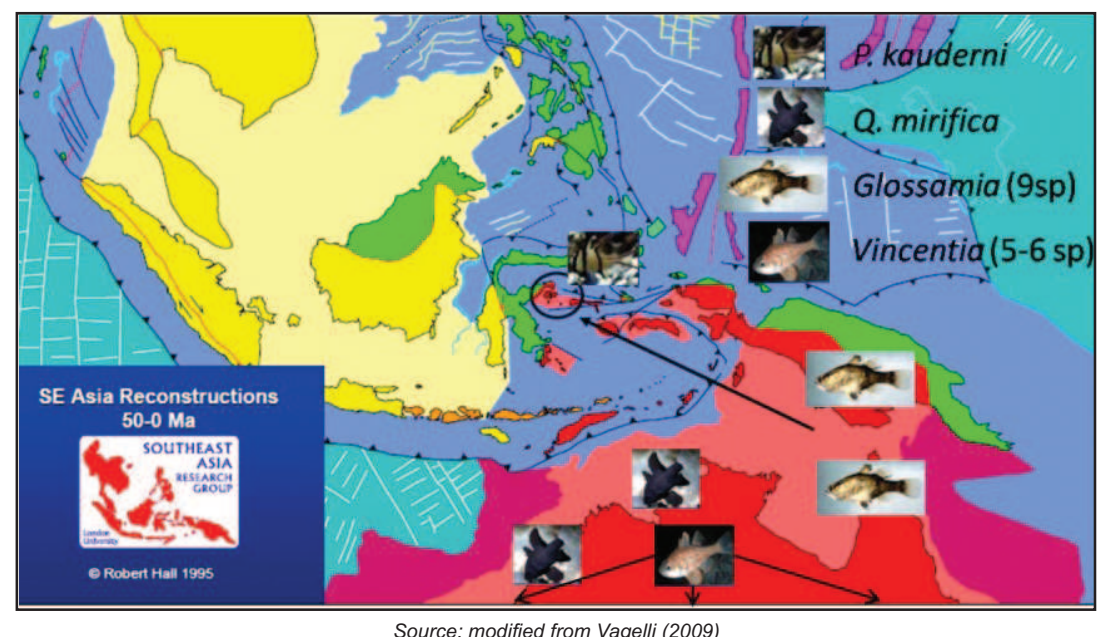

Fig. 4. The theory of plate dispersal and the Australian origin of $P$. kauderni 
We consider that this theory, consistent with historical bathymetry and other geophysical data, could provide a reasonable explanation for the current $P$. kauderni distribution. It is well known that the meeting of plates, each bearing distinctive flora and fauna, contributed to the high biodiversity of Sulawesi Island. Examples of speciation in freshwater fish due to isolation include the ricefishes of the Sulawesi ancient lake complex described in Parenti and Soeroto (2004). However as yet it seems that there are no published data on the genetics of Quinca (or Pterapogon) mirifica or on the Glossamia and Vincentia species so that the proposed evolutionary phylogenic relationships between $P$. kauderni and these species (based on geology and reproductive biology) remain unproven by genetic research methods.

\section{Pterapogon kauderni genetic population structure}

Two methods have been developed for $P$. kauderni genetic analysis. Bernardi and Vagelli (2004) used mitochondrial DNA (mtDNA) haplotypes. Hoffman et al. (2004) identified 11 polymorphic microsatellite DNA loci. These have been registered in GenBank, and used in genetic analysis by Hoffman et al. (2005); Vagelli et al. (2009) and Kolm et al. (2005). Sampling sites for the analysis by Bernardi and Vagelli (2004) and Hoffman et al. (2005) are shown in Fig. 5. Vagelli et al. (2009) also collected samples at 12 sites for a fine-scale analysis of $P$. kauderni population genetics around the island of Bangkulu (synonym Bangkurung), on the western edge of the $P$. kauderni distribution. The genetic analysis in Kolm et al. (2005) was at an extremely

Table 1. Characteristics of 11 polymorphic micro-satellite loci in P. kauderni DNA

\begin{tabular}{|c|c|c|c|c|c|c|c|c|c|}
\hline Locus & $\mathrm{n}^{1}$ & $\begin{array}{l}\text { Sequences } \\
\quad\left(5^{\prime}-3^{\prime}\right)\end{array}$ & $\begin{array}{l}\text { nnealing } \\
\text { temp. } \\
\left({ }^{\circ} \mathrm{C}\right)\end{array}$ & Repeat & $\begin{array}{l}\text { Clone } \\
\text { size } \\
\text { (bp) } \\
\end{array}$ & $\begin{array}{l}\text { No. } \\
\text { Alleles }\end{array}$ & $\mathrm{H}_{\mathrm{o}}{ }^{2}$ & $\mathrm{H}_{\mathrm{e}}{ }^{3}$ & $\begin{array}{c}\text { GenBank } \\
\text { Accession } \\
\text { No. } \\
\end{array}$ \\
\hline Pka 03 & 32 & $\begin{array}{l}\text { *GCTTGATACAACAGTGACAGA } \\
\text { GCGACTGGCAATTTTATAC }\end{array}$ & 54 & $(\text { GATA })_{8}$ & 73 & 6 & 0.781 & 0.715 & Ay530932 \\
\hline Pka 06 & 36 & $\begin{array}{l}\text { *AAGGTTCCACTTCCATCTACT } \\
\text { TCGGTCTTCCACCAATAA }\end{array}$ & 53.5 & $(\text { GATA })_{6}$ & 218 & 10 & 0.722 & 0.774 & AY530933 \\
\hline Pka 07 & 28 & $\begin{array}{l}\text { *CAAGGATTGAGCTATTAACAT } \\
\text { AGGGAGAAGGAATTACAGA }\end{array}$ & 49.5 & $(\text { GATA })_{24}$ & 230 & 14 & 0.786 & 0.883 & AY530934 \\
\hline Pka 09 & 29 & *TGTGTGAAAATTCTAGTG & 49.5 & $(\text { GATA })_{14}$ & 179 & 10 & 0.621 & 0.67 & AY530935 \\
\hline Pka 11 & 27 & *CACACGCACTGATGTTT & 56 & $(\mathrm{GT})_{12} \mathrm{~A}(\mathrm{GATA})_{5}$ & ${ }_{5} 288$ & 2 & 0.111 & 0.107 & AY530936 \\
\hline Pka 13 & 36 & $\begin{array}{l}\text { CGCAGTATCTTAGCTGTTC } \\
\text { *AATGGCTACCTTTACAACTAC }\end{array}$ & 54 & $(\text { GATA })_{24}$ & 209 & 15 & 0.833 & 0.853 & AY530937 \\
\hline Pka 16 & 32 & $\begin{array}{l}\text { AAGGATGGAGGACAGATG } \\
{ }^{*} \text { GGAGCACAGGAACCCCTTTATAC }\end{array}$ & $c^{51}$ & $(\mathrm{GATA})_{23}$ & 153 & 12 & 0.656 & 0.873 & AY530938 \\
\hline Pka 19 & 37 & $\begin{array}{l}\text { CACCGCACCTGGAACAGA } \\
{ }^{*} \text { GGCTTGGGTTTGAGTTCT }\end{array}$ & 54 & $(\mathrm{CTAT})_{11}$ & 199 & 11 & 0.73 & 0.815 & AY530939 \\
\hline Pka 21 & 35 & $\begin{array}{l}\text { CCAGGCTGTGAGTTTGAGAC } \\
{ }^{*} \text { CGCTGAACGAGACTAGATAC }\end{array}$ & 48 & $(\text { GATA })_{15}$ & 185 & 4 & 0.8 & 0.655 & AY530940 \\
\hline Pka 24 & 25 & $\begin{array}{l}\text { TTTGGTATGCTTTTGAATATC } \\
\text { *TCTCCCTGGAAATGTCTC }\end{array}$ & 51 & $(\text { GATA })_{12}$ & 171 & 2 & 0.4 & 0.47 & AY530941 \\
\hline Pka 25 & 30 & $\begin{array}{l}\text { TTCGGACACAGCCAATA } \\
\text { *ATCCCATTGTTCTGAATAA } \\
\text { AGGGAGTTTACTGTAGTCTAAT }\end{array}$ & 51 & $(\mathrm{GATA})_{20}$ & 203 & 15 & 0.933 & 0.928 & AY530942 \\
\hline
\end{tabular}

*5' fluorescent-labelled primer. ${ }^{1} \mathrm{n}$, number of individuals screened from the population,

${ }^{2} \mathrm{H}_{0}$, observed heterozygosity, ${ }^{3} \mathrm{H}_{\mathrm{e}}$, expected heterozygosity 


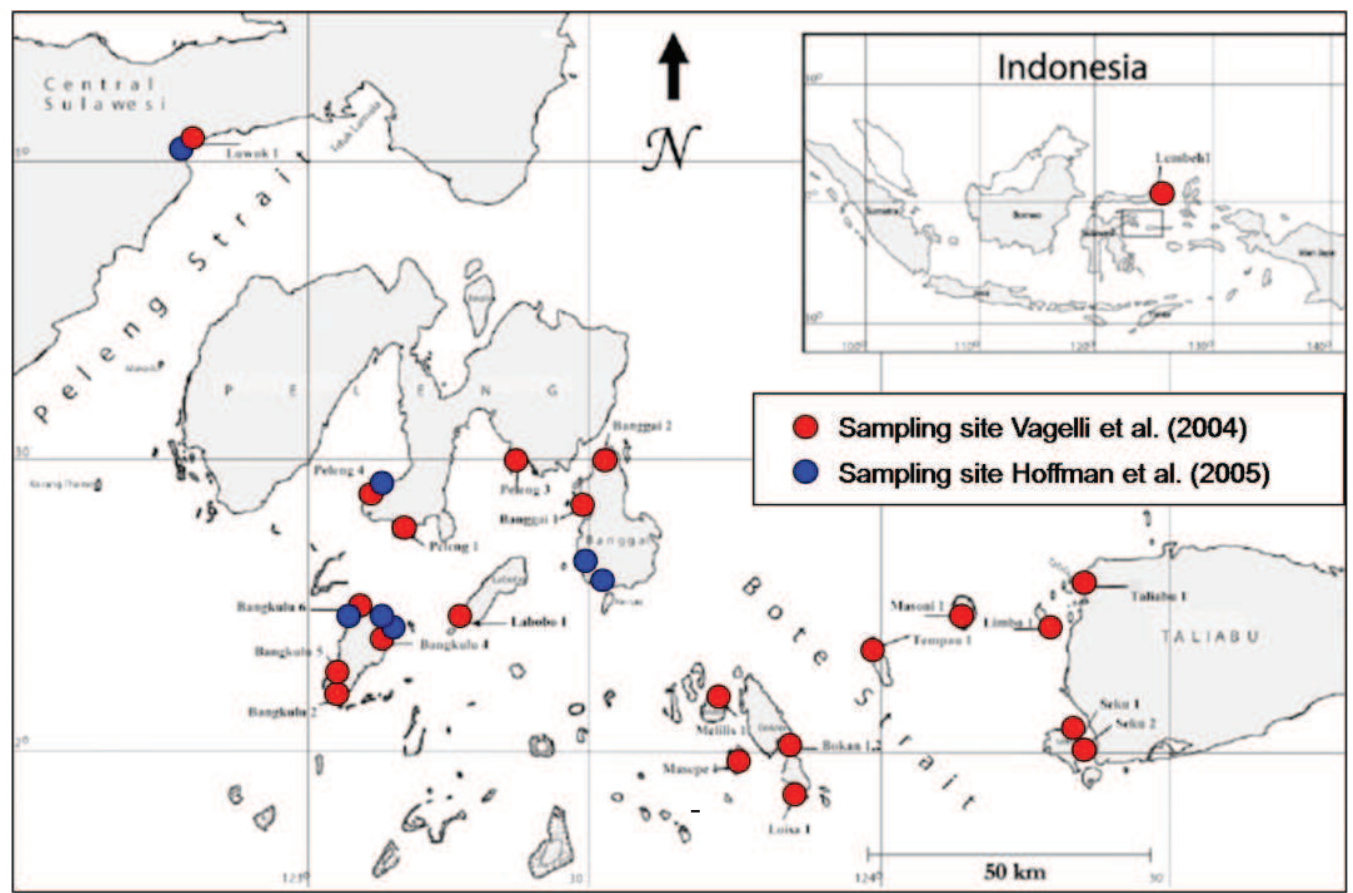

Sources: adapted from Bernardi and Vagelli (2004); Hoffman et al. (2005)

Fig. 5. Sampling locations for $P$. kauderni genetic analysis (2004-2005)

fine scale, aiming to identify the level of kinship within groups of adult $P$. kauderni.

The analysis of genetic distance based on mtDNA data by Bernardi and Vagelli (2004) indicated a reproductive isolation period of around 800,000-160,000 years between the islands of Bangkulu and Banggai. This was based on molecular clocks developed for fish mitochondrial control regions with a rate of $10-2 \%$ per million years (McMillan and Palumbi, 1997, Terry et al., 2000 and Bargelloni et al., 2003 in Bernardi and Vagelli, 2004). Based on historical sea level data (Voris, 2000 in Bernardi and Vagelli, 2004), this distance is consistent with known sea level variation. During periods before this genetic isolation is estimated to have occurred, most of the known $P$. kauderni distribution, including the two islands of Banggai and Bangkulu, would have been joined by shallow waters suitable as Banggai cardinalfish habitat. However it is likely that they would have been separated by deeper waters from most nearby areas where $P$. kauderni is not currently found.

Hoffman et al. (2005) analysed data from 7 sampling sites using the software GENEPOP V.3.3. to calculate expected and observed heterozygosity, Hardy-Weinberg equilibrium (HWE) and genetic distance between populations. FSTAT V.2.9.3.2 was used to test the level of significance. Based on an analysis of all 11 microsatellite loci, a high level of genetic structure was revealed with significant divergence between sites. These differences were considered most likely due to highly restricted gene flow (reproductive isolation) rather than natural selection. A synopsis of the results for two micro-satellite loci considered to represent a significant proportion of the genetic diversity are shown in Fig. 6.

The genetic data give a strong indication that the Luwuk population was introduced rather than being a remnant population. It can be seen in Fig. 6 . that the genetic data for of the Tolokibit (site $\mathrm{H}$ ) and Luwuk (site $\mathrm{R}$ ) populations are very similar. This finding concurs with social survey data reported in Ndobe et al. (2005). Although no longer active in 2004, there had been a trade route from Tolokibit, the southernmost sampling site in Fig. 6. This route began in the 1980's and passed through Luwuk, Banggai cardinalfish were indeed released in Luwuk harbour by the traders involved. 


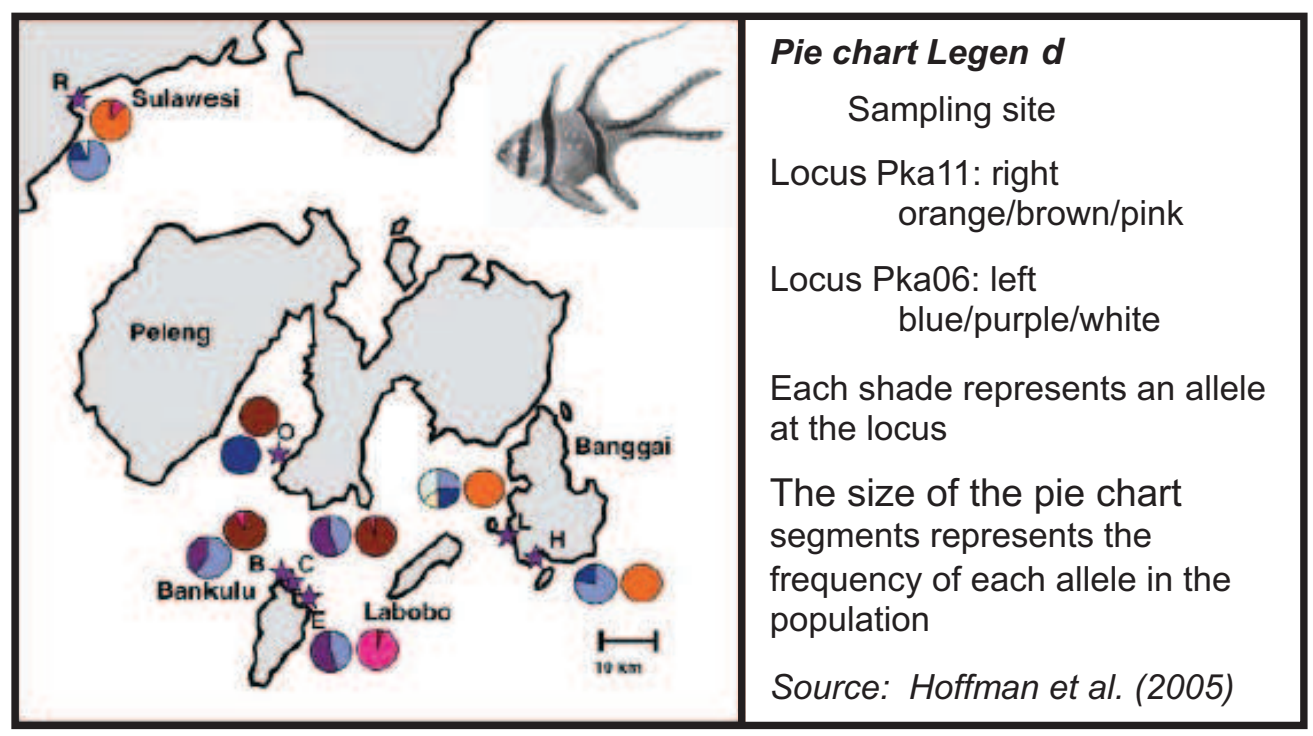

Fig. 6. Genetic variation of 2 loci (Pka 11 and Pka 06) at 7 sampling site

The shortest distance between populations (sites) with significantly different genetic characteristics in a pairwise analysis by Hoffman et al. (2005) was $2 \mathrm{~km}$. The two sites in question were separated by a gap in suitable $P$. kauderni habitat (discontinuous $P$. kauderni distribution). indication of recent bottleneck effects (poor/very poor genetic diversity). Hoffman et al. (2005) highly recommended further genetic population structure research as a basis for conservation and/or sustainable fisheries management. A similar minimum distance between genetically distinct populations was reported by Vagelli et al. (2009). Analysis of the genetic diversity within populations or sites (using the software BOTTLENECK) gave no indication of recent bottleneck effects (poor/very poor genetic diversity). Hoffman et al. (2005) highly recommended further genetic population structure research as a basis for conservation and/or sustainable fisheries management. A similar minimum distance between genetically distinct populations was reported by Vagelli et al. (2009).

Vagelli et al. (2009) carried out a more detailed study of population genetics based on the loci Pka06 and Pka11 identified by Hoffman et al. (2004). This study combined a re-analysis of samples used in the previous mtDNA study (Bernardi and Vagelli, 2004) with intensive sampling of Bangkulu Island which is also known as
Bangkurung (synonym names). The software GENEPOP was used, supplemented by assignment tests using Doh Program (location "fingerprinting"). Three sub-populations or genetically distinct stocks were identified on Bangkulu Island, corresponding to: (1) the northern and eastern sites, (2) the most southern sites and (3) some small islands off west coast. Most of the western coast was reported to have sheer coastline topography with little or no suitable habitat for P. kauderni.

At the overall population level, a high rate of re-assignment was reported by Vagelli et al. (2009), except for the Luwuk and Lembeh introduced populations. The hypothesis was put forward that most mating and most recruitment of juveniles occurs within the site of origin, with a very few individuals moving over short distances. Marked genetic population structure with significant genetic distance between islands was reported.

It was concluded that available data are consistent, and both collectively and severally indicate a high level of genetic structure. Genetic isolation due to habitat gaps recent in geological and evolutionary timescales seems to have resulted in significant genetic distance between $P$. kauderni populations on separate islands. In addition, there are proven examples of genetically distinct populations (stocks) on the same island, separated by gaps in 
suitable habitat. At least two cases have been reported (Ndobe et al., 2005 and Vagelli, 2005) where $P$. kauderni populations extirpated from isolated sites had not been recolonised after a period of several years even though there were healthy $P$. kauderni populations nearby, but separated by relatively deep water. In the case of an islet near Liang Harbour on Peleng Island (Ndobe et al., 2005), severe habitat degradation from coral mining and a one-off incident of severe overfishing were implicated. Based on the available genetic data, it is considered that such local extinctions are likely to result in the total loss (extinction) of genetic strains.

\section{Application to P. kauderni conservation in the banggai Kepulauan district MPA}

The Decree of the Banggai Kepulauan District Head (SK Bupati 540/2007) established the legal basis of a District MPA, or more accurately an MPA network, consisting of 10 islands (see Table 2). The main conservation target for two of these is conservation of the endemic Banggai cardinalfish. In view of the data presented above, it is important that the design of the District MPA should take into account $P$. kauderni genetic diversity and population structure. The MPA has an office (as yet unmanned) in Bone Baru, the main Banggai cardinalfish trading village on Banggai Island, but is still in the early stages of planning process. Priority needs include the establishment of definitive boundaries and zonation.

We consider that the MPA network design is poor from the $P$. kauderni genetic diversity aspect. Much of the known $P$. kauderni distribution is not represented in the MPA. In particular, at least 12 areas already known to have genetically distinct populations (stocks) are not represented. Furthermore, of the 10 islands included in the MPA, only 2 are designated for Banggai cardinalfish protection: Banggai Island, the major $P$. kauderni fishing ground, and Togong Lantang (Tolobundu). Data on Togong Lantang is limited and contradictory. At least 3 other islands within the MPA have $P$. kauderni populations, known or suspected to be genetically distinct stocks, but do not have P. kauderni conservation as a conservation target.

Despite these limitations, on Banggai Island alone it is clear that there are at least two and possibly four or more genetically distinct populations. This factor should be a key management consideration, particularly in zonation both for core zones (no-take conservation approach) and restricted use or buffer zones (sustainable fishery). The planning approach we propose below should enable optimisation of genetic conservation benefits for the islands included in the MPA, and could be extended to other areas of the P. kauderni distribution.

Table 2. The Island in the Banggai District MPA

\begin{tabular}{|c|c|c|c|c|}
\hline No $\begin{array}{c}\text { Site/lsland (alternative/ } \\
\text { synonym name) }\end{array}$ & $\begin{array}{c}\text { Main Conservation } \\
\text { targets* }\end{array}$ & $\begin{array}{l}\text { In known BCF } \\
\text { distribution? }\end{array}$ & $\begin{array}{l}\text { Fishing } \\
\text { Ground }\end{array}$ & $\begin{array}{l}\text { BCF Population } \\
\text { survey(s) }\end{array}$ \\
\hline $\begin{array}{l}\text { 1. PulauTolobundu } \\
\text { (P Togong Lantang) }\end{array}$ & $\mathrm{BCF}, \mathrm{CR}, \mathrm{SG}, \mathrm{M}$ & yes & yes $^{c}$ & 1 site, not found ${ }^{a}$ \\
\hline 2. Pulau Bandang Besar & CR, SG, M, MT & yes & yes $^{b, c}$ & yes, found ${ }^{a}$ \\
\hline 3. Pulau Makaliu & CR, SG & no & no ${ }^{b, c}$ & ves not found ${ }^{a}$ \\
\hline 4. Pulau Lesapuang & $\mathrm{CR}, \mathrm{SG}$ & no & no ${ }^{b, c}$ & \\
\hline $\begin{array}{l}\text { 5. Pulau Togong Sagu } \\
\text { (P. Sago) }\end{array}$ & $\mathrm{M}, \mathrm{CR}$ & no & $\begin{array}{l}\text { No data } \\
\text { (highly }\end{array}$ & 2 sites, not found ${ }^{2}$ \\
\hline 6. Pulau Panteh & $\mathrm{M}, \mathrm{CR}$ & yes & unlikely) & yes, foundd \\
\hline 7. Pulau Maringkih & $\mathrm{M}, \mathrm{CR}$ & no & & yes, not found ${ }^{d}$ \\
\hline 8. Pulau Peposo & CR & no & nob,c & yes, not found ${ }^{a}$ \\
\hline 9. Pulau Sonit (P. Masoni) & $\mathrm{M}, \mathrm{CR}, \mathrm{A}$ & yes & no data & yes, found ${ }^{a}$ \\
\hline 10. Pulau Banggai & $\mathrm{BCF}, \mathrm{M}, \mathrm{CR}$ & yes & yes $^{b, c}$ & yes $^{a, b}$ \\
\hline
\end{tabular}

Sources: SK Bupati 540/2007; Vagelli (2005); Ndobe et al..(2005); Latupono (2009) Artiawan (pers. com, 2011)

${ }^{*} \mathrm{BCF}=$ Banggai cardinalfish; $\mathrm{CR}=$ coral reef; $\mathrm{SG}=$ seagrass; $\mathrm{M}=$ mangroves; $\mathrm{MT}=$ marine tourism; $\mathrm{A}=$ abalone 
Systematic MPA design should take into account the conservation of biodiversity at ecosystem, species and genetic levels as well as economic and social factors and vested interests (Ardron et al., 2010). In order to facilitate this process, data on conservation targets (ecosystems, communities, species, populations/subpopulations etcetera) need to be available in a user-friendly spatial format, and combined with other spatial data (e.g. land use). Maps are the most common media for presenting spatial data. In this Information Technology (IT) era, maps are commonly a part of as well as products of an electronic spatial database or Geographical Information System (GIS).

A GIS Database has many uses in MPA planning (Ehler and Douvere, 2009). In particular a GIS can be a powerful tool for stakeholder consultation, planning and implementing effective conservation management, including the development of sustainable use patterns. Geographical Information System (GIS) software packages are increasingly numerous. ArcGIS (ESRI) products are often used for MPA planning and implementation, including ArcView 3.x: developed in the 1990s which has many compatible applications. MARXAN (Marine Reserve Design using Spatially Explicit Annealing) is an MPA planning software (http://www.uq.edu.au/ MARXAN/; Ardron et al., 2010). The MARXAN software is compatible with ArcView 3.x. via CLUZ application. Both MARXAN \& CLUZ are free (non-commercial) software packages which have been used successfully in many countries (Loos, 2006). In Indonesia examples include the Wakatobi National Marine Park (http://www.reefresilience.org/ Toolkit_Coral/C8 Wakatobi.html) and the Lesser Sunda region (Wilson et al., 2008).
It was considered that the MARXAN application would be appropriate as a planning tool for the Banggai Kepulauan District MPA, in particular in the context of $P$. kauderni conservation.

When using MARXAN as a planning tool, the study area (the proposed or potential MPA area) is divided into planning units, which are usually hexagonal in shape. Each of these units is assigned attributes which will be used to evaluate it's effectiveness in terms of the potential contribution to conservation if it is conserved (FEATURES) and the outlay or loss to other sectors associated with conserving it (COSTS). Key definitions are given in Table 2. A number of other parameters can be set in order to enable the MARXAN model to be more realistic or run more efficiently.

The Output of each RUN is an option of a specific set of priority hexagons to be included in the MPA in order to attain conservation targets with minimum costs. Repeated MARXAN runs with same data/parameters may provide a range of options. The more the input parameters are refined, the more likely that the options from different runs will be similar to one another. The options produced are a scientific basis which can inform stakeholder discussions and planning decisions. Once the key sites have been agreed, the hexagons will most likely need to be squared or rounded off to produce workable MPA boundaries.

The proposed use of MARXAN for the conservation of within species genetic diversity will be a new application of the MARXAN tool. Each sub-population will form a separate MARXAN FEATURE and ArcView GIS layer, with a conservation target expressed as a minimum area or a

Table 3. Key MARXAN Definitions

\begin{tabular}{llll}
\hline \multicolumn{1}{c}{ FEATURES } & \multicolumn{1}{c}{ LOCKIN } & \multicolumn{1}{c}{ COSTS } & \multicolumn{1}{c}{ LOCKOUT } \\
\hline What is to be conserved & Features which must & Other interests (e.g. & Areas which must \\
(e.g.Ecosystems, habitats, & beconserved (e.g. & Aquaculture, fishing & not be within the \\
species). Each must have & Spawning grounds) & grounds, harbours, & core conservation zone \\
values (weighted) and & & touristattractions). Each & (e.g. Harbours) \\
conservation targets & & must comprise spatial & \\
(area orpercent) & & data and values & \\
& & (weighted). & \\
& &
\end{tabular}




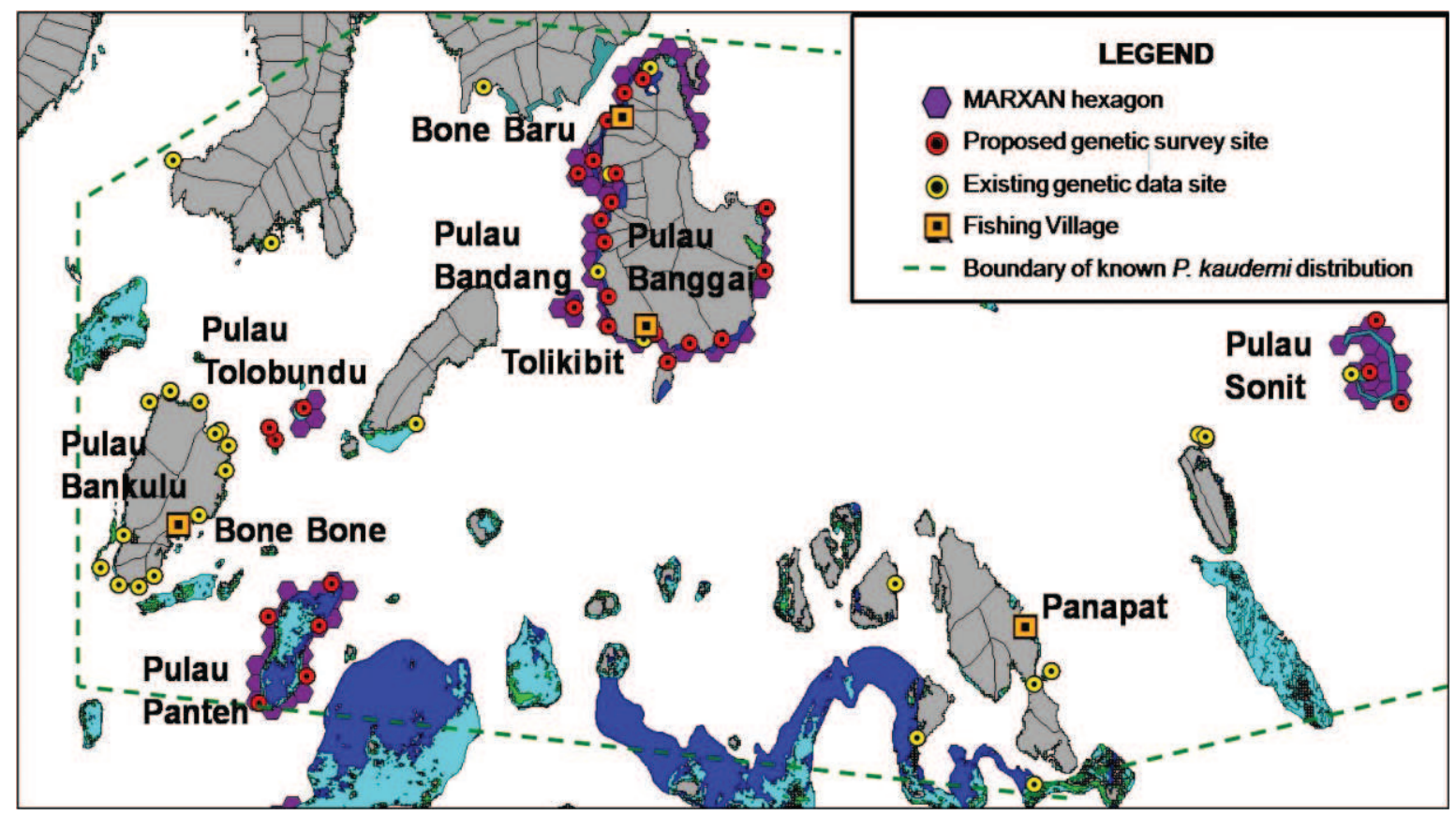

Fig. 7. MARXAN hexagons and proposed sampling sites for a $P$. kaudeni genetic population analysis within the Banggai Kepulauan District MPA

percentage of the feature area. The area to be included is limited to shallow water coastal ecosystems (coral reefs/reef flats, seagrass) which provide known or potential Banggai cardinalfish habitat within the known $P$. kauderni distribution. Therefore the survey and analysis will not include coasts with sheer drop-offs such as much of the East coast of Banggai Island.

The Banggai Kepulauan District MPA can be divided into hexagons, as shown in Fig. 7. In this example the diameter of the hexagons was set at $2 \mathrm{~km}$ based on the smallest known distance between genetically distinct $P$. kauderni subpopulations or stocks. Genetic analysis should enable the identification andcharacterisation of each subpopulation or stock. Combining genetic, geological and ecological data, it should be possible to determine the boundaries between stocks, so that each hexagon can be allocated to a specific stock or subpopulation. Fig. 7 also shows the locations with existing $P$. kauderni genetic data and proposed sampling sites in order to enable such a genetic population analysis for the islands within the District MPA.

In addition to genetic sampling and analysis, other FEATURE and COST data will be necessary to carry out this analysis. These include biophysical data layers (e.g. habitat \& microhabitat) and socioeconomic data layers (e.g. fishing grounds, key infrastructure, coastal development, aquaculture). Once these have been compiled into the MPA database, MARXAN RUNS can provide science-based options for achieving the conservation targets which are set or suggested by managers. Initial runs will provide a basis for a discussion and consultation process. Suggestions from any stakeholders can be entered into the GIS and factored in to further RUNS to predict the effects of specific choices on a conservation targets specifically on conservation of BCF genetic diversity - or indeed to test the costs and benefits associated with changes in the conservation targets themselves. Thereafter, the GIS can be updated with new data and information (e.g. additional surveys or genetic analysis, planned infrastructure development etc), before and after the management plan and management mechanisms are in place, specifically including data from monitoring programs. This will make the GIS a valuable tool for adaptive management as well as planning. 


\section{CONCLUSION}

As for most of the Family Apogonidae, there are many questions regarding the phylogeny of the Genus Pterapogon and species $P$. kauderni, including the relationship of $P$. kauderni to several taxa from the Australian plaque. Knowledge and techniques for P. kauderni genetic (DNA) analysis which can be used for effective genetic population structure analysis have been developed, and genetically distinct sub-populations have been identified at distances as little as $2-5 \mathrm{~km}$ apart, within coastal waters of the same island as well as between islands. Each genetically distinct sub-population or stock should be considered as a separate management unit. There are big gaps in the geographical coverage of $P$. kauderni genetic population data, in particular within the Banggai Kepulauan District MPA.

Recommendations for MPA planning include: (i) the establishment of genetic sub-populations (stocks) as a spatial management unit in the planning and management of $P$. kauderni conservation in the Banggai Kepulauan District MPA, including specifically in the zonation process, and as far as practicable (most likely excluding areas where significant introductions and mixing have taken place) for fisheries management; (ii) research to complete the identification of $P$. kauderni genetic sub-populations and the geographical boundaries between them, the first priority being the two islands designated for BCF conservation (Banggai and Togong Lantang); (iii) establish conservation targets for each subpopulation within the MPA (e.g. as FEATURES in MARXAN)

General recommendations include: (i) extreme care in re-stocking or in-situ breeding/culture to avoid/minimise the mixing of BCF sub-populations as this could affect population genetic diversity and/or fitness; (ii) the development and implementation of a $P$. kauderni population dynamics model and fisheries management tools at genetic subpopulation (stock) level, not only for the endemic population as a whole; (iii) further research into $P$. kauderni phylogeny \& reproductive biology, including the relationship with Apogonidae from Australia
(Quinca/ Pterapogon mirifica, Genus Vincentia and Genus Glossamia).

\section{REFERENCES}

Allen G.R. and T.J. Donaldson. (2007). Pterapogon kauderni. In: IUCN 2009. IUCN Red List of Threatened Species. Version 2009.1. (http://www.iucnredlist.org, downloaded 11 July 2009)

Ardron J.A., H.P. Possingham and C.J. Klein (eds). (2010). Marxan Good Practices Handbook, Version 2. Pacific Marine Analysis and Research Association, Victoria, BC, Canada

Bernardi G. and A. Vagelli (2004). Population structure in Banggai cardinalfish, Pterapogon kauderni, a coral reef species lacking a pelagic larval phase. Marine Biology (2004) 145: 803-810

Bertorelle G., M.W. Bruford, H.C. Hauffe, A. Rizzoli and C. Vernesi (2009). Population Genetics for Animal Conservation. Cambridge University Press, Cambridge, UK.

Bruins E.B.A., M.A. Moreau, K.E. Lunn, A.A. Vagelli and $\mathrm{H}$. Hall (2004). 10 Years after rediscovering the Banggai Cardinalfish. Musée Océanographique, Monaco. Bulletin de l'Institut Océanographique 2004, vol. 77, no1446, pp. 71-81

CITES (2007a). COP 14 Prop. XX. Convention on the International Trade in Endangered Species, Fourteenth meeting of the Conference of the Parties, The Hague (Netherlands), 3-15 June 2007, Consideration of Proposals for Amendment of Appendices I and II. Proposal: Inclusion of the Banggai cardinalfish (Pterapogon kauderni, Koumans 1933) in Appendix II of CITES. (http://www.cites.org, downloaded 21 January, 2007)

CITES (2007b). Summary record of the 10th session of Committee I. E14-Com-I-Rep-10. (http://www.cites.org, downloaded 24 June 2007)

Conover D. O., L.M. Clarke, S.B. Munch. and G.N. Wagner. (2006). Spatial and temporal scales of adaptive divergence in marine fishes and the implications for conservation. Journal of Fish Biology 69 (Supplement C):21-47

Ehler C. and F. Douvere. (2009). Marine Spatial Planning: a step-by-step approach toward ecosystem-based management. Intergovernmental Oceanographic Commission and Man and the Biosphere Programme. IOC Manual and Guides No. 53, ICAM Dossier No. 6. UNESCO, Paris, France.

Erdmann M.V. and A.A. Vagelli (2001). Banggai Cardinalfish Invade Lembeh Strait. Coral Reefs 20:252-253.

Frazer T.H. (1972). Comparative osteology of the shallow water cardinalfishes [Perciformes: Apogonidae] with reference to the systematics and evolution of the family. Ichthyological bulletin 34:1-105 
the family. Ichthyological bulletin 34:1-105

Gouws G. and O. Gon, (2009). A preliminary molecular phylogeny of Apogon and related genera. Paper presented at the 8th IndoPacific Fish Conference, 1-5 June 2009. (http://www.ipfc2009asfb.com/pdf/speaker presentations/Gouws, Gavin.pdf, downloaded 26 August, 2009)

Gray J.S. (1997). Marine Biodiversity: Patterns, Threats and Conservation Needs. Biodiversit and Conservation 6:153-175

Hellberg M.E. (2007). Footprints on water: the genetic wake of dispersal among reefs. Coral Reefs, DOI 10.1007/s00338-007-0205-2.

Hoffman E.A., Arguello J.R., Kolm N., Berglund A. and Jones A.G. (2004). Eleven polymorphic microsatellite loci in a coral reef fish, Pterapogon kauderni. Molecular Ecology Notes (2004) 4 pp. 342-344

Hoffman E.A., Kolm N., Berglund A., Arguello J.R. and Jones A.G. (2005). Genetic structure in the coral-reef-associated Banggai cardinalfish, Pterapogon kauderni. Blackwell Publishing Ltd.Molecular Ecology (2005) 14, 1367-1375.

Indrawan M. and Suseno (2008). The complications of CITES inclusion of endemic species in Indonesia: Lessons learned from an in-country deliberation on protecting the Banggai cardinalfish, Pterapogon kauderni. SPC Live Reef Fish Information Bulletin \#18:13-16

Kolm N., Hoffman E.A., Olsson J., Berglund A., and Jones A.G. (2005). Group stability and homing behaviour but no kin group structures in a coral reef fish. Behavioural Ecology 16:521-527

Koumans, F. P. 1933. On a new genus and species of Apogonidae. Zoologische Mededeelingen (Leiden) 16 (1-2): 78, PI. 1.

Latupono F. (2009). Data Enumerator BCF Tahun 2009 (Excel file)

Lilley R. (2008). The Banggai cardinalfish: An overview of conservation challenges. SPC Live Reef Fish Information Bulletin \#18:3-12

Loos S.A. (2006). Exploration of MARXAN for Utility in Marine Protected Area Zoning. A Thesis Submitted in Partial Fulfilment of the Requirements for the Degree of Master of Science in the Department of Geography, University of Victoria, Canada.

Moore A. and Ndobe S. (2007a). Discovery of an introduced Banggai Cardinalfish population in Palu Bay, Central Sulawesi, Indonesia. Coral Reefs 26:569.

Moore A. and Ndobe S. (2007b). The Banggai Cardinalfish and CITES - a local perspective. Reef Encounters Vol.38:15-17.

Moore A., Ndobe S. and Zamrud M. (2011). Monitoring the Banggai Cardinalfish, an Endangered Restricted Range Endemic Species. Paper presented at the 2nd Coral Reef Management Symposium on Coral TriangleArea.

Ndobe S. and Moore A. (2009). Banggai cardinalfish: towards a sustainable ornamental fishery. Proceedings of the 11th International Coral Reef Symposium, Ft. Lauderdale, Florida, 7-11 July 2008 pp.1026-1029

Ndobe S., Madinawati and Moore A. (2008). Pengkajian Ontogenetic Shift pada Ikan Endemik Pterapogon kauderni. Jurnal Mitra Bahari. Vol 2 No.2:32-55

Ndobe S., Moore A. \& Supu A. (2005). Sulawesi Case Study - Banggai Kepulauan. Pages 5143 \& 165-229 in The Indonesian Ornamental Fish Trade: Case Studies and Options for Improving Livelihoods while Promoting Sustainability in Banggai and Banyuwangi. The International Seafood Trade: Supporting Sustainable Livelihoods Among Poor Aquatic Resource Users in Asia (EC Prep Project EP/RO3/R14). Poseidon and Network of Aquaculture Centres in Asia (NACA) STREAM.

Palumbi S.R. (2003). Population Genetics, Demographic Connectivity, and the Design of Marine Reserves. Ecological Applications, 13(1) Supplement: S146-S158

Parenti L.R. and Soeroto B. (2004). Adrianichthys roseni and Oryzias nebulosus, two new ricefishes (Atherinomorpha: Beloniformes: Adrianichthyidae) from Lake Poso, Sulawesi, Indonesia. Ichthyol Res 51: 10-19

Reiss H., Hoarau G., Dickey-Collas. M and Wolf W.J. (2009). Genetic population structure of marine fish: mismatch between biological and fisheries management units. Fish and Fisheries 10:361-395

Rocha L.A., Craig M.T. and Bowen B.W. (2007). Phylogeography and the conservation of coral reef fishes. Coral Reefs, DOI 10.1007/s00338-007-0261-7

Thacker C.E. (2009). Phylogeny of Gobioidei and Placement within Acanthomorpha, with a New Classification and Investigation of Diversification and Character Evolution. Copeia, 2009(1):93-104. 2009

Thacker C.E. and Roje D.M. (2009). Phylogeny of cardinalfishes (Teleostei: Gobiiformes: Apogonidae) and the evolution of visceral bioluminescence. Molecular Phylogenetics and Evolution 52:735-745

Vagelli A. (1999). The Reproductive biology and early ontogeny of the mouthbrooding Banggai Cardinalfish, Pterapogon kauderni (Perciformes, Apogonidae). Environmental Biology of Fishes 56:79-92

Vagelli A.A. \& Erdmann M.V. (2002). First Comprehensive Survey of the Banggai Cardinalfish, Pterapogon kauderni. Environmental Biology of Fishes 63:1-8

Vagelli A.A. (2005). Reproductive Biology, Geographic Distribution and Ecology of the Banggai Cardinalfish Pterapogon kauderni Koumans, 1933 (Perciformes, Apogonidae), with Considerations on the Conservation Status of this Species on its Natural Habitat. PhD. Dissertation, University of Buenos Aires, Argentina 
Vagelli A.A. (2008). The unfortunate journey of Pterapogon kauderni: A remarkable apogonid endangered by the international ornamental fish trade, and its case in CITES. SPC Live Reef Fish Information Bulletin \#18:17-28

Vagelli A.A. (2009). The reproductive biology of Quinca mirifica (Apogonidae). Can it help to clarify the evolution of direct development and intergeneric relation ships in apogonids? Paper presented at the 8th Indo - Pacific Fish Conference, 1-5 June 2009. (http://www.ipfc2009asfb.com/pdf/speaker presentations/Vagelli,Alejandro.pdf, downloaded 26 August, 2009)

Vagelli A.A., Burford M. and Bernardi G. (2009). Fine scale dispersal in Banggai Cardinalfish, Pterapogon kauderni, a coral reef species lacking a pelagic larval phase. Marine Genomics 1:129-134.

Vié, J.-C., Hilton-Taylor, C. and Stuart, S.N. (eds.) (2009). Wildlife in a Changing World An Analysis of the 2008 IUCN Red List of Threatened Species. Gland, Switzerland: IUCN

Wilson J., Darmawan A., Subijanto J., Green A., and Sheppard S. (2011). Scientific design of a resilient network of marine protected areas. Lesser Sunda Ecoregion, Coral Triangle. The Nature Conservancy Asia Pacific Marine Program. Report 2/11. http://conserveonline.org/workspaces/tncc oral triangle/documents/resilient-mpanetworklesser-sunda-ecoregion/ (downloaded 22 July 2011) 